\title{
MENINGKATKAN KEMAMPUAN BAHASA ANAK MELALUI METODE TANYA JAWAB DENGAN MEDIA KARTU BERGAMBAR DI KELOMPOK B TK AL-KHAIRAAT 1 DESA KOTAPULU KECAMATAN DOLO KABUPATEN SIGI
}

\author{
Tri Putri Regita ${ }^{1)}$ Sri Dewi Lisnawati ${ }^{2)}$ Hikmatur Rahmah ${ }^{3)}$ \\ ${ }^{1}$ Mahasiswa Program Studi PIAUD FTIK Institut Agama Islam Negeri Palu \\ ${ }^{2}$ Dosen Fakultas Tarbiyah dan Ilmu Keguruan Institut Agama Islam Negeri Palu \\ ${ }^{3}$ Dosen Fakultas Tarbiyah dan Ilmu Keguruan Institut Agama Islam Negeri Palu
}

\begin{abstract}
ABSTRAK
Penelitian ini membahas tentang Meningkatkan Kemampuan Bahasa Anak Melalui Metode Tanya Jawab Dengan Media Kartu Bergambar di Kelompok B TK Al-Khairaat 1 Kotapulu Kecamatan Dolo Kabupaten Sigi. Penelitian ini menggunakan Penelitian Tindakan Kelas (PTK), teknik pengumpulan data melalui observasi, dokumentasi, dan wawancara. Teknik analisis melalui lembar observasi pada siklus I dan siklus II. Setelah data terkumpul, lalu dianalisis secara kualitatif dan kuantitatif untuk mengetahui proses tindakan. Selanjutnya dinarasikan untuk mengambil kesimpulan tentang ada tidaknya peningkatan kemampuan bahasa anak melalui metode tanya jawab dengan media kartu bergambar. Hasil penelitian meningkatkan kemampuan bahasa anak melalui metode tanya jawab dengan media kartu bergambar di kelompok B TK Al -Khairaat 1 Desa Kotapulu pada siklus I tindakan I adalah sebesar $24.44 \%$, tindakan II adalah sebesar $39.99 \%$. Adapun peningkatkan kemampuan bahasa anak melalui metode tanya jawab dengan media kartu bergambar di kelompok B TK Al -Khairaat 1 Desa Kotapulu pada siklus II tindakan I adalah sebesar $57.77 \%$, tindakan II adalah sebesar $86.66 \%$ telah mencapai yang diharapkan peneliti dalam kategori Berkembang Sangat Baik (BSB). Berdasarkan hasil penelitian di atas maka disimpulkan bahwa metode tanya jawab dengan media kartu bergambar dapat meningkatkan kemampuan bahasa anak di kelompok B TK Al-Khairaat 1 Desa Kotapulu Kecamatan Dolo Kabupaten Sigi.
\end{abstract}

Kata Kunci : Kemampuan Bahasa Anak, Metode Tanya Jawab, Media Kartu Bergambar.

\section{PENDAHULUAN}

Anak usia dini merupakan anak yang berada pada usia 0-6 tahun. Pada anak yang usia 0 s/d 6 tahun pada masa ini disebut sebagai "The Golden Age" atau "Usia Masa Emas" (0 s/d 6 tahun). Masa ini sangat penting dan tidak dapat tergantikan lagi apabila sudah terlewati, karena di masa ini, adalah masa untuk mempersiapkan segenap potensi fisik, akal maupun mental yang ada 
pada seorang manusia dengan sebaik-baiknya dan menghargai setiap keunikan per individu dari setiap insan. Dalam hal ini masa golden age sangatlah berperan penting dalam memberikan stimulasi aspek perkembangan bagi pertumbuhan anak selanjutnya.

Adapun hal yang dapat di lakukan dalam mengisi kegiatan di usia emas ini dengan mengikutkan anak di lembaga pendidikan anak usia dini yang saat ini telah banyak diselenggarakan di masyarakat. Tujuannya adalah untuk memberikan pendidikan informal yang berfungsi dalam menggali potensi anak yang belum nampak dengan pengembangan pembelajaran dengan menekankan pada aktivitasnya. Dalam proses perkembangan inilah diperlukan adanya pendidikan yang dapat mengembangkan potensi dalam diri anak karena proses pendidikan dasar sangatlah berguna bagi pembentukan kepribadian manusia. Adapun pengertian pendidikan menurut Hasbullah "Pendidikan adalah usaha manusia untuk membina kepribadiannya sesuai dengan nilainilai didalam masyarakat dan kebudayaan. ${ }^{1}$

Pendidikan mempunyai peran penting dalam menentukan perkembangan, salah satunya perkembangan bahasa. Dalam mengembangkan bahasa, orang dewasa dituntut untuk menuturkan perkataan yang baik terhadap anak, seperti yang telah tercantum dalam Al-Qur'an Surah Al-Baqarah ayat 31 yaitu:
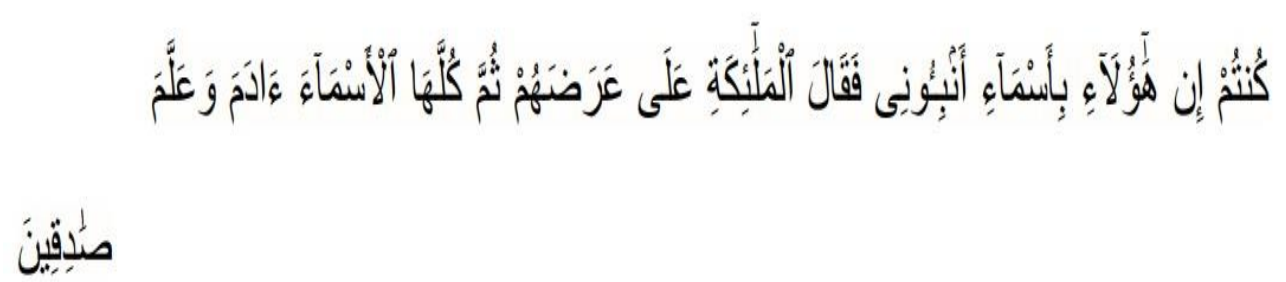

Terjemahannya:

Dia mengajarkan kepada Adam nama-nama (benda-benda) Dan seluruhnya, kemudian mengemukakannya kepada para Malaikat lalu berfirman: "Sebutkanlah kepada-Ku nama benda-benda itu jika kamu memang benar orang-orang yang benar. ${ }^{2}$

Pada ayat di atas terungkap bahwa yang pertama kali Allah ajarkan kepada Nabi Adam AS adalah bahasa yaitu untuk mengungkapkan isi pikiran, lalu Nabi Adam AS dapat menyebutkan benda-benda dengan simbol-simbol bahasa dan bahasa juga sebagai alat komunikasi di dalam kehidupan.

${ }^{1}$ Hasbullah, Dasar-Dasar Ilmu Pendidikan (Jakarta: Raja Grafindo Persada, 2009), 1.

${ }^{2}$ Departemen Agama RI, Al-Qur'an dan Terjemah (Jakarta: Pustaka Al-Hanan, 2009), 14 
Bahasa adalah sistem lambang bunyi ujaran yang digunakan untuk berkomunikasi oleh masyarakat. ${ }^{3}$ Bahasa memegang peranan penting dalam kehidupan manusia karena bahasa merupakan alat komunikasi manusia dalam kehidupan sehari-hari. Peranan bahasa bagi anak usia dini diantaranya sebagai sarana untuk berpikir, sarana untuk mendengarkan, sarana untuk berbicara dan sarana agar anak mampu membaca dan menulis. Diharapkan baik orang tua di lingkungan keluarga dan guru di lingkungan sekolah agar dapat memberikan stimulus pada anak agar perkembangan bahasa khususnya bahasa lisan anak dapat berkembang secara optimal. Bahasa lisan berfungsi sebagai salah satu alat komunikasi dan merupakan sarana penting dalam kehidupan anak. Melalui bahasa lisan, anak dapat saling berhubungan, saling berbagi pengalaman, dan dapat meningkatkan intelektual, yakni dalam rangka pengembangan pengetahuan dan kemampuan bahasanya.

Salah satu upaya pendidik di sekolah yaitu dengan melatih anak didik untuk selalu berkomunikasi dengan metode tanya jawab. Penerapan metode tanya jawab akan mampu memberikan hasil yang lebih optimal dalam pembelajaran dan diharapkan dapat meningkatkanperkembangan bahasa anak.

Metode tanya jawab adalah metode mengajar yang memungkinkan terjadinya komunikasi langsung yang bersifat dua arah sebab pada saat yang sama terjadi dialog antara guru dan anak didik. Guru bertanya anak didik menjawab, ataupun sebaliknya. ${ }^{4}$ Metode tanya jawab merupakan suatu teknik untuk memberi motivasi anak didik agar bangkit pemikirannya untuk bertanya, selama mendengarkan ajaran atau guru yang mengajukan pertanyaanpertanyaan itu mengenai isi ajaran yang sedang diajarkan guru dan anak didik seharusnya sudah mengerti atau pertanyaan yang lebih luas asal berkaitan dengan ajaran, atau juga mungkin pengalaman yang dihayati dengan tanya jawab itu, ajaran akan lebih mendalam dan meluas.

Selain penggunaan metode yang tepat dalam proses pembelajaran maka diperlukan juga media yang sesuai yang dapat mengembangkan aspek perkembangan pada anak. Dalam hal ini peneliti menggunakan media kartu bergambar karena menurut penulis, kartu bergambar lebih mudah menarik perhatian peserta didik, apalagi usia di bawah 6 tahun. Mereka lebih cenderung menyukai sesuatu yang bergambar.

Berdasarkan hasil observasi dan wawancara pada TK Alkhairaat 1 Desa Kotapulu, masih banyak anak didik yang kurang memperhatikan saat guru

${ }^{3}$ Widjono, Bahasa Indonesia. (Jakarta: Grasindo, 2012), 20.

${ }^{4}$ R.Ibrahim dan Nana Syaodih, Perencanaan Pengajaran (Jakarta: Rineka Cipta, 2010), 106. 
memberikan penjelasan di depan kelas. Anak lebih senang berbicara dengan temannya dibandingkan harus mendengarkan penjelasan guru. Hal ini dikarenakan guru tidak menggunakan metode pembelajaran bervariatif dan menarik dalam proses pembelajaran, sehingga anak menjadi jenuh dan bosan dalam mengikuti proses pembelajaran. Dalam mencapai perkembangan yang optimal maka metode dan media sangat dibutuhkan dalam meningkatkan perkembangan anak khususnya perkembangan bahasa (bahasa lisan) anak, hal ini membuat penulis mengusulkan kepada guru yang di sekolah tersebut untuk mencoba menggunakan metode tanya jawab dengan menggunakan media kartu bergambar untuk menarik perhatian anak didik.

Inilah yang melatar belakangi penulis mengambil judul "Meningkatkan Kemampuan Bahasa Anak Melalui Metode Tanya Jawab Dengan Media Kartu Bergambar di Kelompok B TK Al-Khairaat 1 Desa Kotapulu Kecamatan Dolo Kabupaten Sigi”.

\section{METODE PENELITIAN}

Penelitian ini adalah jenis Penelitian Tindakan Kelas (PTK). Melalui penelitian tindakan, subjek penelitian ini adalah anak di Kelompok B Tk AlKhairaat 1 Desa Kotapulu. yang berjumlah dari 15 anak terdiri 7 anak laki-laki dan 8 anak perempuan.

Pelaksanaan penelitian tindakan ini mempunyai tahapan yang bersiklus. Rancangan penelitian ini mengacu pada siklus pelaksanaan penelitian tindakan model John Elliot, seperti pada gambar tiap siklus dilakukan beberapa tahap, yaitu 1) Perencanaan tindakan, 2) Pelaksanaan Tindakan, 3) Observasi, dan 4) Refleksi. ${ }^{5}$

Teknik pengumpulan data yang digunakan adalah teknik observasi, dokumentasi dan wawancara. Analisis data dilakukan oleh peneliti terhadap hasil pengamatan yang diperoleh melalui lembar observasi pada siklus I. setelah data terkumpul, lalu dianalisis secara kualitatif dan kuantitatif untuk mengetahui proses tindakan. Selanjutnya dinarasikan untuk mengambil kesimpulan tentang ada tidaknya peningkatan hubungan interpersonal pada anak melalui implementasi model pembelajaran sentra bermain peran dengan menggunakan pedoman dari Ditjen Mandas Diknas 2010 dengan kategori sebagai berikut:

${ }^{5}$ Mahmud, Metode Penelitian Pendidikan, ( Cet. 1; Bandung: Pustaka Setia, 2011), 221. 


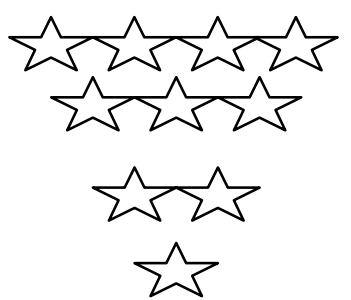

: Berkembang Sangat Baik (BSB)

: Berkembang Sesuai Harapan (BSH)

: Mulai Berkembang (MB)

: Belum Berkembang (BB) ${ }^{6}$

Setelah data terkumpul, selanjutnya data akan diolah dengan menggunakan teknik persentase, hasil olahan tersebut kemudian dianalisis secara deskriptif untuk mengetahui persentasi keberhasilan tindakan.

\section{HASIL DAN PEMBAHASAN}

\section{A. Pra Tindakan}

Langkah awal dari penelitian ini, penulis melakukan observasi awal untuk melihat sampai dimana kemampuan bahasa peserta didik. Kegiatan pra tindakan umumnya dilakukan sebelum penulis memulai penelitian terhadap meningkatkan kemampuan bahasa anak melalui metode tanya jawab dengan media kartu bergambar di kelompok B TK Alkhairaat 1 Kotapulu.

Tabel 1 Rekapitulasi Hasil Pengamatan Kelompok B Pratindakan Meningkatkan Kemampuan Bahasa Anak Melalui Metode Tanya Jawab Dengan Media Kartu Bergambar

\begin{tabular}{|c|c|c|c|c|c|c|c|}
\hline & \multicolumn{7}{|c|}{ Meningkatkan Kreativitas Anak } \\
\hline & \multicolumn{2}{|c|}{$\begin{array}{l}\text { Memahami } \\
\text { bahasa }\end{array}$} & \multicolumn{2}{|c|}{$\begin{array}{l}\text { Mengungkapkan } \\
\text { bahasa }\end{array}$} & \multicolumn{2}{|c|}{ Keaksaraan } & \multirow{2}{*}{$\%$} \\
\hline & $\mathbf{F}$ & $\%$ & $\mathbf{F}$ & $\%$ & $\mathbf{F}$ & $\%$ & \\
\hline $\begin{array}{l}\text { Berkembang } \\
\text { Sangat } \\
\text { Baik }\end{array}$ & 2 & 13.33 & 2 & 13.33 & 2 & 13.33 & 13.33 \\
\hline $\begin{array}{l}\text { Berkembang } \\
\text { Sesuai } \\
\text { Harapan }\end{array}$ & 2 & 13.33 & 2 & 13.33 & 2 & 13.33 & 13.33 \\
\hline $\begin{array}{l}\text { Mulai } \\
\text { Berkembang }\end{array}$ & 4 & 26.66 & 4 & 26.66 & 3 & 20 & 24.44 \\
\hline $\begin{array}{l}\text { Belum } \\
\text { Berkembang }\end{array}$ & 7 & 46.66 & 7 & 46.66 & 8 & 53.33 & 48.90 \\
\hline Jumlah & 15 & 100 & 15 & 100 & 15 & 100 & 100 \\
\hline
\end{tabular}

${ }^{6}$ Johni Dimyati, Metodologi Penelitian Pendidikan dan Aplikasinya pada Pendidikan Anak Usia Dini /PAUD (Cet. 2; Jakarta: Kencana, 2014), 96. 
Berdasarkan rekapitulasi tabel sebelumnya, setelah dirata-ratakan ketiga aspek yang diamati terdapat $13.33 \%$ dalam kategori berkembang sangat baik (BSB), 13.33\% dalam kategori berkembang sesuai harapan (BSH), 24.44\% dalam kategori ini mulai berkembang (MB), dan $48.90 \%$ dalam kategori belum berkembang (BB).

Setelah meilihat hasil nilai rata-rata yang telah dijelaskan pada pra tindakan di kelompok B dapat dilihat sebagian besar $48.90 \%$ peserta didik dikategorikan belum berkembang dalam meningkatkan kemampuan bahasa anak melalui metode tanya jawab dengan media kartu bergambar, sedangkan dalam kategori berkembang sangat baik terdapat $13.33 \%$, oleh karena itu penulis melakukan penelitian untuk tindakan kelas.

\section{B. Tindakan Siklus 1}

Pada tahapan ini disiklus I, peneliti malakukan proses belajar dan mengajar di dalam kelas berdasarkan RPPH yang telah dibuat untuk mengajar untuk meningkatkan kemampuan bahasa anak melalui metode tanya jawab dengan media kartu bergambar. Di dalam tindakan siklus I ini, peneliti melakukan 2 kali pertemuan di kelompok B untuk meningkatkan kemampuan bahasa anak melalui metode tanya jawab dengan media kartu bergambar.

Tabel 2 Rekapitulasi Hasil Pengamatan Tindakan I dan II Siklus I Terhadap Meningkatkan Kemampuan Bahasa Anak Melalui Metode Tanya Jawab dengan Media Kartu Bergambar di Kelompok B

\begin{tabular}{|c|c|c|c|c|c|c|c|}
\hline \multirow{3}{*}{$\begin{array}{l}\text { Kategori } \\
\text { Tindakan I }\end{array}$} & \multicolumn{7}{|c|}{ Meningkatkan Kemampuan Bahasa Anak } \\
\hline & \multicolumn{2}{|c|}{$\begin{array}{l}\text { Memahami } \\
\text { bahasa }\end{array}$} & \multicolumn{2}{|c|}{$\begin{array}{l}\text { Mengungkapkan } \\
\text { bahasa }\end{array}$} & \multicolumn{2}{|c|}{ Keaksaraan } & \multirow[b]{2}{*}{$\%$} \\
\hline & $\mathbf{F}$ & $\%$ & $\mathbf{F}$ & $\%$ & $\mathbf{F}$ & $\%$ & \\
\hline $\begin{array}{l}\text { Berkembang } \\
\text { Sangat Baik }\end{array}$ & 3 & 20 & 3 & 20 & 5 & 33.33 & 24.44 \\
\hline $\begin{array}{l}\text { Berkembang } \\
\text { Sesuai Harapan }\end{array}$ & 2 & 13.33 & 3 & 20 & 3 & 20 & 17.78 \\
\hline Mulai Berkembang & 6 & 40 & 4 & 26.66 & 3 & 20 & 28.89 \\
\hline $\begin{array}{l}\text { Belum } \\
\text { Berkembang }\end{array}$ & 4 & 26.66 & 5 & 33.33 & 4 & 26.66 & 28.89 \\
\hline Jumlah & 15 & 100 & 15 & 100 & 15 & 100 & 100 \\
\hline Tindakan II & & & & & & & \\
\hline
\end{tabular}




\begin{tabular}{|l|l|l|l|l|l|l|l|}
\hline $\begin{array}{l}\text { Berkembang } \\
\text { Sangat Baik }\end{array}$ & 5 & 33.33 & 6 & 40 & 7 & 46.66 & 39.99 \\
\hline $\begin{array}{l}\text { Berkembang } \\
\text { Sesuai Harapan }\end{array}$ & 4 & 26.66 & 4 & 26.66 & 4 & 26.66 & 26.67 \\
\hline Mulai Berkembang & 5 & 33.33 & 5 & 33.33 & 2 & 13.33 & 26.67 \\
\hline $\begin{array}{l}\text { Belum } \\
\text { Berkembang }\end{array}$ & 1 & 6.66 & 0 & 0 & 2 & 13.33 & 6.67 \\
\hline Jumlah & 15 & 100 & 15 & 100 & 15 & 100 & 100 \\
\hline
\end{tabular}

Berdasarkan rekapitulasi tabel, setelah dirata- ratakan ketiga aspek yang diamati dari tindakan I dan II dari siklus I di kelompok B. Hasil tindaka I terdapat $24.44 \%$ dalam kategori berkembang sangat baik (BSB), $17.78 \%$ dalam kategori berkembang sesuai harapan (BSH), 28.88\% dalam kategori ini mulai berkembang (MB), dan $28.88 \%$ dalam kategori belum berkembang (BB). Hasil dari tindakan II terdapat 39.99\% dalam kategori (BSB), 26.67\% dalam kategori berkembang sesuia harapan (BSH), 26.67 dalam kategori mulai berkembang (MB), dan $6.67 \%$ dalam kategori belum berkembang (BB).

Melihat hasil persentase tindakan I dan II pada siklus I di kelompok B terhadap meningkatkan kemampuan bahasa anak melalui metode tanya jawab dengan media kartu bergambar, jelas terlihat bahwa presentase yang diperoleh dari tiga aspek pengamatan memahami bahasa, mengungkapkan bahasa dan keaksaraan mulai ada peningkatan dari siklus I mulai tindakan I yaitu $24.44 \%$ dalam kategori berkembang sangat baik dan tindakan II 39.99\%. Namun peneliti ingin meningkatkan kemampuan bahasa anak melalui metode tanya dengan media kartu bergambar menjadi 86\% dalam kategori berkembang sangat baik (BSB). Berdsarkan hasil tersebut, penulis melakukan tindakan siklus II.

\section{Hasil Pengamatan Siklus II}

Pada tahapan ini disiklus I, penulis malakukan prosese belajar dan mengajar di dalam kelas berdasarkan RPPH yang telah dibuat untuk mengajar untuk meningkatkan kemampuan bahasa anak melalui metode tanya jawab dengan media kartu bergambar. Di dalam tindakan siklus I ini, peneliti melakukan 2 kali pertemuan di kelompok B untuk meningkatkan kemampuan bahasa anak melalui metode tanya jawab dengan media kartu bergambar.

Penulis melakukan tindakan I dan tindakan II pada siklus I, dimulai membuat perencanaan, pelaksanaan, observasi, dan refleksi. Saat penyajian materi, peneliti bertindak sebagai pengajar atau guru. 
Tabel 3 Rekapitulasi Hasil Pengamatan Tindakan I dan II Siklus II Terhadap Meningkatkan Kemampuan Bahasa Anak Melalui Metode Tanya Jawab dengan Media Kartu Bergambar di Kelompok B

\begin{tabular}{|c|c|c|c|c|c|c|c|}
\hline \multirow{3}{*}{\begin{tabular}{|l} 
Kategori \\
Tindakan I \\
\end{tabular}} & \multicolumn{7}{|c|}{ Meningkatkan Kreativitas Anak } \\
\hline & \multicolumn{2}{|c|}{$\begin{array}{l}\text { Memahami } \\
\text { bahasa }\end{array}$} & \multicolumn{2}{|c|}{$\begin{array}{l}\text { Mengungapkan } \\
\text { bahasa }\end{array}$} & \multicolumn{2}{|c|}{ Keaksaraan } & \multirow[b]{2}{*}{$\%$} \\
\hline & $\mathbf{F}$ & $\%$ & $\mathbf{F}$ & $\%$ & $\mathbf{F}$ & $\%$ & \\
\hline $\begin{array}{l}\text { Berkembang } \\
\text { Sangat Baik }\end{array}$ & 7 & 46.66 & 10 & 66.66 & 9 & 60 & 57.77 \\
\hline $\begin{array}{c}\text { Berkembang } \\
\text { Sesuai Harapan }\end{array}$ & 7 & 46.66 & 4 & 26.66 & 4 & 26.66 & 33.32 \\
\hline Mulai Berkembang & 1 & 6.66 & 1 & 6.66 & 1 & 6.66 & 6.67 \\
\hline Belum Berkembang & 0 & 0 & 0 & 0 & 1 & 6.66 & 2.24 \\
\hline Jumlah & 15 & 100 & 15 & 100 & 15 & 100 & 100 \\
\hline \multicolumn{8}{|l|}{ Tindakan II } \\
\hline $\begin{array}{l}\text { Berkembang } \\
\text { Sangat Baik }\end{array}$ & 13 & 86.66 & 13 & 86.66 & 13 & 86.66 & 86.66 \\
\hline $\begin{array}{c}\text { Berkembang } \\
\text { Sesuai Harapan }\end{array}$ & 2 & 13.33 & 2 & $\begin{array}{c}13.3 \\
3\end{array}$ & 2 & $\begin{array}{c}13.3 \\
3\end{array}$ & 13.33 \\
\hline Mulai Berkembang & 0 & 0 & 0 & 0 & 0 & 0 & 0 \\
\hline Belum Berkembang & 0 & 0 & 0 & 0 & 0 & 0 & 0 \\
\hline \begin{tabular}{|l|} 
Jumlah \\
\end{tabular} & 15 & 100 & 15 & 100 & 15 & 100 & 100 \\
\hline
\end{tabular}

Berdasarkan rekapitulasi tabel, setelah dirata- ratakan ketiga aspek yang diamati dari tindakan I dan II dari siklus I di kelompok B. Hasil tindaka I terdapat $57.77 \%$ dalam kategori berkembang sangat baik (BSB), 33.32\% dalam kategori berkembang sesuai harapan (BSH), $6.67 \%$ dalam kategori ini mulai berkembang (MB), dan 2.24\% dalam kategori belum berkembang (BB). Hasil dari tindakan II terdapat $86.66 \%$ dalam kategori (BSB), $13.33 \%$ dalam kategori berkembang sesuai harapan $(\mathrm{BSH}), 0 \%$ dalam kategori mulai berkembang (MB), dan $0 \%$ dalam kategori belum berkembang (BB).

Melihat hasil presentase tindakan I dan II pada siklus I di kelompok B terhadap meningkatkan kemampuan bahasa anak melalui metode tanya jawab dengan media kartu bergambar, jelas terlihat bahwa presentase yang diperoleh dari tiga aspek pengamatan memahami bahasa, mengungkapkan bahasa dan keaksaraan mulai ada peningkatan dari siklus I mulai tindakan I yaitu $24.44 \%$ dalam kategori berkembang sangat baik dan tindakan II 39.99\%. Namun peneliti ingin meningkatkan kemampuan bahasa anak melalui metode tanya dengan media 
kartu bergambar menjadi $86 \%$ dalam kategori berkembang sangat baik (BSB). Berdsarkan hasil tersebut, penulis melakukan tindakan siklus II.

\section{KESIMPULAN}

Berdasarkan hasil pembahasan dalam penelitian ini, maka penulis mengemukakan beberapa kesimpulan yaitu:

1. Penerapan metode tanya jawab dengan media kartu bergambar dapat meningkatkan kemampuan bahasa anak di kelompok B TK Al-Khairaat 1 Kotapulu. Hal ini sesuai dengan pencapaian yang diharapkan oleh penulis pada setiap aspek yang dikembangkan pada meningkatkan kemampuan bahasa anak melalui metode tanya jawab dengan media kartu bergambar.

2. Hasil pencapaian penerapan Kelompok B pada siklus I menigkatkan kemampuan bahasa anak melalui metode tanya jawab dengan media kartu bergambar pada tindakan I persentasenya yaitu $24.44 \%$ dalam kategori berkembang sangat baik (BSB) seddangkan pada tindakan II persentasenya yaitu 39.99\% dalam kategori berkembang sangat baik (BSB). Hal tersebut belum mencapai sesuai harapan peneliti untuk mencapai $86 \%$ dalam kategori berkembang sangat baik. Hasil siklus II di kelompok B tindakan I persentasenya yaitu $57.77 \%$ dalam kategori berkembang sangat baik (BSB), sedangkan pada tindakan II siklus II persentasenya yaitu $86.66 \%$ dalam kategori berkembang sangat baik (BSB). Hal tersebut telah mencapai sesuai harapan peneliti untuk mencapai $86 \%$ dalam kategori berkembang sangat baik (BSB).

\section{SARAN}

Berdasarkan kesimpulan diatas, ada beberapa saran yang perlu disampaikan antara lain:

1. Kepala sekolah hendaknya menambah media pembelajaran di TK Al- Khairaat 1 Desa Kotapulu salah satunya media kartu bergambar.

2. Guru hendaknya menciptakan suasana kelas yang nyaman, ceria saat proses pembelajaran.

3. Guru hendaknya menerapkan metode pembelajaran yang kreatif, menarik perhatian peserta didik dan tidak membuat mereka bosan. 


\section{DAFTAR PUSTAKA}

Departemen Agama RI, Al-Qur'an dan Terjemah. Jakarta: Pustaka Al-Hanan, 2009.

Dimyati, Johni. Metodologi Penelitian Pendidikan dan Aplikasinya pada Pendidikan Anak Usia Dini /PAUD. Cet. 2; Jakarta: Kencana, 2014.

Hasbullah, Dasar-Dasar Ilmu Pendidikan. Jakarta: Raja Grafindo Persada, 2009.

Ibrahim, R. dan Syaodih, Nana. Perencanaan Pengajaran. Jakarta: Rineka Cipta, 2010.

Mahmud, Metode Penelitian Pendidikan, Cet. 1; Bandung: Pustaka Setia, 2011.

Widjono, Bahasa Indonesia. Jakarta: Grasindo, 2012. 